\title{
INTERVENSI PEMERINTAH INDONESIA DALAM MENETAPKAN HARGA BBM DITINJAU DARI MEKANISME PASAR ISLAM
}

\author{
Yenti Afrida \\ Lecturer of Syari'ah PPs Faculty at IAIN Imam Bonjol Padang \\ Jl. Prof. Mahmud Yunus Lubuk Lintah Kota Padang, Sumatera Barat 25153 \\ Email: yen_afrida@gmail.com
}

\begin{abstract}
This paper aims to explain the Indonesian government intervention in setting the price of fuel in terms of market mechanisms Islam. In a market system adopted Islam is a free market system. Price left to the forces of demand and supply. The government is not allowed to intervene in the price of a normal state. The government is only justified in case of emergency. The intervention price in Indonesia aims to kemaslahan people not overly burdened with the cost of fuel when oil shot up.
\end{abstract}

Keyword: BBM, tas'ir al-jabari, mekanisme pasar.

\begin{abstract}
Abstrak
Tulisan ini bertujuan untuk menjelaskan intervensi pemerintah Indonesia dalam menetapkan harga bahan bakar dalam hal mekanisme pasar Islam. Dalam sistem pasar mengadopsi Islam adalah sistem pasar bebas. Harga diserahkan kepada kekuatan permintaan dan penawaran. pemerintah tidak diperbolehkan untuk campur tangan dalam harga keadaan normal. pemerintah hanya dibenarkan dalam keadaan darurat. Harga intervensi di Indonesia bertujuan untuk kemaslahatan orang tidak terlalu dibebani dengan biaya bahan bakar saat minyak melonjak.
\end{abstract}

Kata Kunci: BBM, tas'ir al-jabari, market mechanism.

\section{PENDAHULUAN}

Persoalan energi menjadi wacana hangat yang sering diperbincangkan di belahan dunia. Mulai dari meningkatnya harga minyak dunia, spekulasi di komoditas minyak sampai dengan subtitusi energi fosil ke bioful yang mengancam produksi pangan. Di Indonesia wacana ini tidak kalah serunya, masyarakat disuguhi pemberitaan menurunnya lifting minyak dalam negeri yang diikuti dengan tren meningkatnya impor minyak nasional. ${ }^{1}$

Sejatinya, wacana pentingnya energi dalam perekonomian bukan hal yang baru lagi. Bahkan kalau mau ditelusuri lebih jauh bisa ditarik mulai sejak adanya kegiatan ekonomi itu sendiri. Namun, dalam perkembangannya wacana ini juga mengalami pasang surut seiring fluktuasi ekonomi yang terjadi dan kiblat ekonomi yang dianut. Minyak-komoditas energi yang paling dominan digunakan dalam kegiatan ekonomi bisa dijadikan gambaran

${ }^{1}$ Eko Listiyanto, Kenaikan Harga Minyak Dunia : Penyebab dan Dampaknya terhadap Subsidi Energi di Indonesia, Jurnal Bisnis dan Ekonomi Politik Quarterly Review of The Indonesian Economy Subsidi dalam Perekonomian Indonesia, Volume 9, Nomor 3, Juli 2008, hal 10 
perkembangan wacana energi selama ini. Fluktuasi harga minyak dunia mewartakan bahwa minyak sebagai energi eksklusif dalam perekonomian tidak hanya sensitif terhadap isu ekonomi tetapi juga geopolitik, kondisi alam dan perminyakan dunia.

Melonjaknya harga minyak dunia tentu akan menyebabkan instabilitas perekonomian dibanyak negara terutama negara berkembang. Di Indonesia, melambungnya harga minyak menyebabkan pembengkakan anggaran subsidi. Kondisi seperti itu memaksa pemerintah mengeluarkan kebijakan pengurangan subsidi, dari sisi politik, pengurangan subsidi BBM merupakan suatu bentuk kebijakan yang tidak popular dan berpotensi menyulut konflik vertikal antara rakyat dan pemerintah.

Terlebih lagi pengurangan subsidi ini terjadi disaat masyarakat sudah terbebani oleh meningkatnya harga komoditas pangan dunia. Selama ini harga BBM di Indonesia berdasarkan ketentuan pemerintah, tanpa terikat langsung dengan fluktuasi harga internasional. Tujuannya menurunkan harga guna percepatan pembangunan ekonomi. Dengan BBM yang lebih terjangkau diharapkan akan mampu memacu pertumbuhan melalui meningkatnya berbagai kegiatan ekonomi seperti industri, transportasi dan distribusi barang dan jasa.

Secara teoritis kebijakan subsidi BBM merupakan kebijakan pemerintah dalam rangka membantu konsumen (masyarakat) agar mendapatkan harga BBM pada tingkat harga yang lebih murah dengan sebagian beban harga ditanggung pemerintah. Dengan harga yang lebih terjangkau maka akan semakin banyak masyarakat yang bisa mengakses BBM. Pada gilirannya penggunaan BBM akan meningkatkan pertumbuhan ekonomi melalui makin aktifnya kegiatan produksi dan distribusi barang dan jasa termasuk kegiatan transportasi.

Di Indonesia, sejak beberapa dekade terakhir pemerintah punya prioritas penuh dalam menetapkan harga BBM. Harga BBM sering mengalami naik turun. Dalam satu tahun bisa tertadi tiga kali fluktuasi harga BBM. Hal ini yang selalu menjadi polemik di Indonesia. Setiap kali pemerintah berencana menaikkan harga BBM bersubsidi maka masyarakat akan protes dengan demonstrasi besar-besaran.

Dalam tulisan ini, penulis menggunakan wacana naik turunnya harga BBM di Indonesia dan subsidi yang dilakukan oleh pemerintah. Penulis akan menghubungkannya dengan mekanisme pasar Islam. Sistem pasar dalam Islam adalah pasar bebas. Harga didasarkan pada kekuatan permintaan dan penawaran. Pemerintah tidak dibenarkan melakukan intervensi harga. Kecuali dalam keadaan darurat.

\section{LATAR BELAKANG}

Kisruh kenaikan harga BBM di Indonesia selalu menjadi topik hangat pada pemerintah berencana menaikkan harga BBM. Disetiap ada rencana pemerintah untuk menaikan harga BBM masyarakat selalu mengadakan demonstrasi besar-besaran untuk 
mencegah kenaikan harga tersebut. Padahal usaha demonstrasi itu tidak pernah membuahkan hasil. Pemerintah akan tetap menaikkan harga BBM sesuai dengan rencana awal. Karena di Indonesia selama ini harga minyak tidak diserahkan pada mekanisme pasar.

Alur naik turunnya harga BBM terjadi dari masa era orde baru sampai sekarang. Pada Era Presiden Soeharto, harga BBM mengalami kenaikan sebanyak empat kali selama delapan tahun terakhir pemerintahan dimulai dari tahun 1980 harga BBM mulai Rp.150, tahun 1991 harga BBM naik menjadi Rp.550, tahun 1993 harga BBM kembali naik menjadi Rp.700, dan tahun 1998 harga BBM naik lagi menjadi Rp.1.200. Kemudian pada masa presiden BJ Habibie harga BBM mengalami penurunan dari Rp.1.200 menjadi Rp.1.000.

Pada masa pemerintahan Presiden Abdurahman Wahid Tahun 1998 harga BBM dimulai dengan harga Rp.1.000turun pada tahun 1999 menjadi Rp.600, pada tahun 2000 harga BBM kembali naik menjadi Rp.1.150 dan pada tahun 2001 kembali mengalami kenaikanmenjadi Rp.1.450. Kemudian pada masa pemerintahan Megawati Soekarno Putri, $\begin{array}{lllll}\text { tahun } & 2002 & \text { harga } & \text { BBM } & \text { mulai }\end{array}$ kemudian Tahun 2003 harga BBM mengalami kenaikan menjadi Rp.1.810.

Selanjutnya pada masa pemerintahan presiden Susilo Bambang Yudhoyono, pada tahun 2003 harga BBM mulai Rp.1.810, pada Maret 2005 harga BBM meningkat menjadi Rp.2.400, dan masih pada bulan Maret 2005 harga BBM kembali naik manjadi Rp.4.500. Pada bulanMei 2008 harga BBM kembali naik menjadi Rp.6.000 dan pada November 2008 harga BBM mengalami penurunan menjadi Rp.5.500, selanjutnya pada Desember 2008 harga BBM kembali turun menjadi Rp.5.000. Tahun 2009 harga BBM turun menjadi Rp4.500 dan tahun 2013 harga BBM kembali naik menjadi Rp.6.500. ${ }^{2}$

Pemerintahan presiden Jokowi yang baru dimulai sejak Oktober 2014 sudah mencatat dua kali menaikkan dan menurunkan harga BBM. Di mulai dengan harga Rp. 6.500 naik menjadi Rp. 8.500 pada bulan November 2014. Kemudian turun Rp. 7.600, dan pada 19 Januari 2015 kemaren harga BBM kembali diturunkan menjadi Rp. 6.600. Turunnya harga BBM mengikuti turunnya harga minyak dunia saat ini. Hal ini diungkapkan oleh Sofyan Djalil selaku Menteri Koordinator Perekonomian. ${ }^{3}$

Terkait anjloknya harga minyak dunia, Sofyan mengatakan, penurunan harga BBM subsidi juga menjadi kajian pemerintah."Turunnya minyak dunia akan dirasakan rakyat. Revisi harga (BBM subsidi)termasuk opsi yang dipikirkan. yang membuat masalah ini tidak berulangulang," jelas Sofyan. Sofyan mengatakan, pemerintah menginginkan kebijakan yang sifatnya permanen. Sebagaimana diketahui, selama ini pemerintah selalu dipusingkan dengan

\footnotetext{
${ }^{2}$ Economy Okezone, From : http://economy.okezone.com/read/2014/08/28/19/1030923/sejarah-harga-bbmsubsidi-di-indonesia, 27 Januari 2015, 15.00

${ }^{3}$ Tineberita, From: http://tinoberita.blogspot.com/2014/12/harga-bbm-akan-turun-di-akhir-tahun.html. 27 Januari 2015, 15.10
} 
membengkaknya beban subsidi karena naiknya konsumsi atau lonjakan harga minyak dunia. "Kita ingin masalah itu tidak terulang-ulang," ucapnya.

Salah satu opsi yang dinilai bisa menjadi solusi permanen atas permasalahan subsidi BBM adalah skema subsidi yang dipatok di angka tetap atau fixed subsidy. Dengan skema tersebut, harga BBM subsidi akan naik turun mengikuti harga keekonomian BBM.

Yang menjadi permasalahan di Indonesia sekarang adalah subsidi BBM sudah dihapuskan dan dialokasikan ke sektor lain. Bila harga BBM didasarkan pada mekanisme pasar, maka masyarakat yang akan menanggung sendiri kenaikan harga BBM apabila harga minyak dunia melonjak naik. Pertanyaannya adalah bila terjadi minyak dunia melonjak naik kembali apakah pemerintah akan melakukan intervensi atau tidak?

\section{MEKANISME PASAR ISLAMI}

Berbicara mengenai mekanisme pasar dalam hukum Islam yang pertama menjadi dasar hukum yaitu Al-Qur'an, walaupun dalam Al-Qur'an tidak memberikan aturan secara jelas tentang apa itu mekanisme pasar. Namun demikian sebagai manusia yang dilengkapi akal maka kita akan dapatkan aturan main tentang pasar yaitu seperti apa yang tersebut dalam Al-Qur'an surat An-Nisa ayat $29: 4$

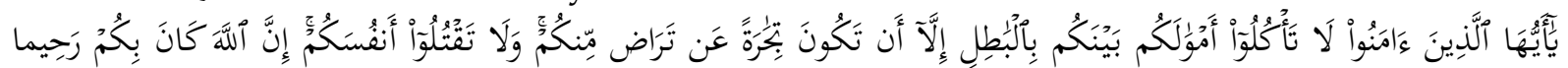

Artinya :"Hai Orang-orang yang beriman, janganlah kamu saling memakan harta sesamamu dengan jalan yang bathil, kecuali dengan jalan perniagaan yang berlaku dengan suka sama suka diantara kamu, dan janganlah kamu membunuh dirimu, sesungguhnya Allah adalah Maha penyayang kepadamu." (QS. An-Nisa : 4)

M. Quraish Shihab dalam tafsirnya, Al Misbah menafsirkan ayat tersebut sebagai berikut. Dalam konteks ekonomi, ayat tersebut menyebutkan beberapa prinsip penting dalam berekonomi. Pertama adalah kata amwaalakum yang dimaksud adalah harta yang beredar dalam masyarakat. ${ }^{5} \mathrm{Kedua}$ adalah albathil yakni pelanggaran terhadap ketentuan agama atau persyaratan yang disepakati. Dalam konteks ini, Nabi Muhammad SAW bersabda : "kaum muslimin sesuai dengan (harus menepati) syarat-syarat yang mereka sepakati, selama tidak mengahalalkan yang haram atau mengharamkan yang halal"6dan selanjutnya adalah kata yang mengharuskan adanya kerelaan kedua belah pihak yaitu prinsip 'antaradhin minkum. Walaupun kerelaan adalah hal yang tersembunyi di dalam hati, tetapi indicator dan tanda-tandanya dapat terlihat. Ijab dan Kabul, atau apa saja yang dikenal dalam adat kebiasaan sebagai serah terima adalah bentuk-bentuk yang digunakan hukum untuk menunjukkan kerelaan. Dari tafsir tersebut terlihat jelas apa yang menjadi prinsip dasar aktifitas pasar.

${ }^{4}$ Arif Wahyudi, Telaah Kritis Pemikiran Ekonomi Islam terhadap Mekanisme Pasar dalam Konteks Ekonomi Islam Kekinian, Jurnal Eksyar, Volume 01, Nomor 01, Maret 2014 STAI Muhammadiyah Tulung Agung, hal 56

${ }^{5}$ M. Quraish Shihab, Tafsir Al Misbah (Jakarta:Lentera hati, 2002), hal 412

${ }^{6}$ Ibid, hal 413 
Pasar memegang peranan penting dalam perekonomian masyarakat Muslim pada masa Rasulullah SAW. dan Khulafaurrasyidin. Bahkan Nabi Muhammad sendiri pada awalnya adalah seorang pebisnis demikian pula khulafaurrasyidin dan kebanyakan sahabat. Pada usia 7 tahun sudah pergi berdagang ke Negeri Syam. Seiring berjalannya waktu Nabi semakin giat berdagang dan menjalin mitra dengan saudagar kaya yaitu Siti Khadijah yang akhirnya menjadi istri beliau. Nabi adalah seorang pedagang professional dan menjunjung tinggi kejujuran. Pada saat itu mekanisme pasar sangat dihargai. Beliau menolak untuk membuat kebijakan penetapan harga manakala tingkat harga pada saat itu tiba-tiba naik. Sepanjang kenaikan terjadi karena kekuatan permintaan dan penawaran yang murni, yang tidak dibarengi dengan dorongan-dorongan monopolistik dan monopsonistik, maka tidak ada alasan untuk tidak menghormati harga pasar. ${ }^{7}$

Pasar adalah sebuah mekanisme pertukaran barang dan jasa yang alamiah dan telah berlangsung sejak peradaban awal manusia. Islam menempatkan pasar pada kedudukan yang penting dalam perekonomian. Praktik ekonomi pada masa Rasulullah dan Khulafaurrasyidin menunjukkan adanya peranan pasar yang besar. Rasulullah sangat menghargai harga yang dibentuk oleh pasar sebagai harga yang adil. Beliau menolak adanya suatu price intervention seandainya perubahan harga terjadi karena mekanisme pasar yang wajar. Namun, pasar di sini mengharuskan adanya moralitas, antara lain : persaingan yang sehat (fair play), kejujuran (honesty), keterbukaan (Transparancy) dan keadilan (justice). Jika nilai-nilai ini telah ditegakkan, maka tidak ada alasan untuk menolak harga pasar. ${ }^{8}$

Dewasa ini, kemunculan pesan moral Islam dalam pencegahan teori pasar, dapat dikaitkan sebagai bagian dari reaksi penolakan sosialisme dan sekularisme, ataupun secara khusus ideologi-ideologi yang sudah banyak diasumsikan orang sebagai sistem yang merusak pasar dan memposisikan diri sebagai oposisi dari paham pasar bebas dan terbuka di dunia Arab. Ajaran Islam dengan tegas menolak sejumlah ideologi ekonomi yang terkait dengan keagungan privat property, kepentingan investor, asceticism (menghindari kehidupan duniawi), economic egalitarianism maupun authoritarianism (ekonomi terpimpin atau paham mematuhi seseorang atau badan secara mutlak). ${ }^{9}$

Konsep Islam menegaskan bahwa pasar harus berdiri di atas prinsip persaingan bebas (perfect competition). Namun demikian bukan berarti kebebasan tersebut berlaku mutlak, akan tetapi kebebasan yang dibungkus oleh frame aturan syariah ${ }^{10}$.

Pada dasarnya dalam sistem ekonomi Islam, mekanisme pasar dibangun atas dasar kebebasan, yakni kebebasan individu untuk melakukan transaksi barang dan jasa.

7Pusat Pengkajian dan Pengembangan Ekonomi Islam (P3EI), Ekonomi Islam, (Jakarta : Rajawali Pers, 2009), hal 302

8Ibid, hal 301

${ }^{9}$ Mustafa Edwin Nasution, Pengenalan Ekflusif Ekonomi Islam, (Jakarta : Kencana, 2007), hal 158.

${ }^{10}$ Ibid. 
Sistem ekonomi Islam menempatkan kebebasan pada posisi yang tinggi dalam kegiatan ekonomi, walaupun kebebasan itu bukanlah kebebasan mutlak seperti yang dianut paham kapitalis. Namun, kebebasan itu diikat dengan aturan. Yaitu tidak melakukan kegiatan ekonomi yang bertentangan dengan aturan syariat, tidak menimbulkan kerugian bagi para pihak yang bertransaksi, dan senantiasa melakukan kegiatan ekonomi dalam rangka mewujudkan kemaslahatan. ${ }^{11}$

Pemikiran tentang mekanisme pasar, sudah menjadi perhatian para ulama klasik, beribu-ribu tahun yang lalu, seperti Abu Yusuf (731-798), Al-Ghazali (1058-1111), Ibnu Taimiyah (1263-1328), Ibnu Khaldun (1332-1383). Al-Ghazali menjelaskan proses evolusi pasar, secara alami manusia selalu membutuhkan orang lain, petani membutuhkan ikan yang ada pada nelayan sebaliknya nelayan membutuhkan beras yang ada pada petani dan lain sebagainya.

Abu Yusuf menyatakan tidak ada batasan tertentu tentang murah dan mahalnya harga di pasar. Murah bukan karena melimpahnya makanan, demikian juga mahal bukan karena kelangkaan makanan, kadang makanan sangat sedikit tetapi harganya murah. Murah dan mahal merupakan sunnatullah (Ketentuan Allah). Harga bukan hanya ditentukan oleh supply (penawaran) semata, tetapi juga ditentukan oleh demand (permintaan).

Ibnu Taimiyah memiliki pandangan yang hampir sama dengan ini. Ia menyatakan mekanisme pasar dalam Islam adalah pasar bebas, harga ditentukan oleh kekuatan penawaran dan permintaan. Kenaikan harga tidak selalu disebabkan oleh ketidakadilan dari para pedagang, harga merupakan hasil interaksi antara permintaan dan penawaran yang terbentuk karena faktor yang komplek. Terkadang naik turunnya harga disebabkan oleh defenisi produksi atau penurunan terhadap barang permintaan atau tekanan pasar. Jika permintaan terhadap barang meningkat, sedangkan kesediaan barang menurun maka harga akannaik. Begitu pun sebaliknya.

Ibnu Khaldun menyatakan pendapat yang hampir sama, dalam kitabnya Muqaddimah jika suatu kota berkembang dan jumlah penduduknya semakin banyak, penuh dengan kemewahan maka harga barang-barang pokok akan menurun, sedangkan barang mewah akan menjadi naik.

Sistem ekonomi Islam menganut prinsip pasar bebas dan pasar persaingan sempurna. Negara dalam sistem ekonomi Islam tidak dapat ikut campur dalam kegiatan pasar. Akan tetapi, negara mempunyai wewenang melakukan pengawasan terhadap mekanisme pasar, mencegah dan menindak pelaku kecurangan, spekulasi seperti penimbunan barang, monopoli dan tindakan lainnya yang merugikan konsumen.

${ }^{11}$ Rozalinda, Ekonomi Islam Teori dan Aplikasinya pada Aktivitas Ekonomi, (Jakarta : Rajawali Pers, 2014), hal 
Dengan mengacu kepada kehidupan pasar pada masa Rasulullah dan sikap yang diambil Rasulullah dalam menghadapi kenaikan harga di pasar, merupakan bentuk dari mekanisme pasar islami, dapat dijelaskan sebagai berikut:

1. Orang bebas keluar masuk pasar.

2. Adanya informasi yang cukup mengenai kekuatan-kekuatan pasar dan barangbarang dagangan.

3. Unsure-unsur monopolistic harus dilenyapkan dari pasar.

4. Kenaikan dan penurunan harga disebabkan oleh naik turunnya permintaan.

5. Adanya homogenitas dan standarisasi produk agar terhindar dari pemalsuan produk, penipuan dan kecurangan tentang kualitas produk.

6. Terhindar dari penyimpangan terhadap kebebasan ekonomi yang jujur seperti sumpah palsu, keecurangan dalam timbangan, ukuran dan pelaku pasar juga dilarang menjual barang-barang haram. ${ }^{12}$

Menurut Ibnu Taimiyah dalam kitab "Majmu Fatawa" perilaku atau etika yang harus diperhatikan seorang penjual atau merupakan prinsip-prinsip pasar yang efisien antara lain :13

1. Dilarang Menipu

Segala praktik kecurangan, termasuk penipuan dilarang dalam Islam. Hal ini sesuai hadits Rasulullah SAW yang diriwayatkan Muslim dimana Rasulullah SAW pernah melewati sebuah wadah berisi makanan, lantas beliau memasukkan tangan beliau ke dalamnya, ternyata jari-jari beliau menyentuh sesuatu yang basah. Kemudian beliau bertanya, "Apakah ini wahai pemilik makanan?" pemilik makanan menjawab: “Terkena air hujan wahai Rasulullah". Beliau mengatakan mengapa kamu tidak meletakkannya dibagian atas agar dapat dilihat orang lain. Barang siapa yang mencurangi kami, maka ia bukan golongan kami" (H.R Muslim).

Praktik kecurangan tersebut antara lain menyembunyikan barang cacat, mengurangi timbangan, ukuran dan sebagainya. Jika penjual bertindak curang terhadap timbangannya, ukuran, jenis dan nilai maka pengaruhnya terhadap pembeli adalah : daya pembeli berkurang dan meningkatkan nilai jual barang yang dibeli bila ia jual kembali.

2. Akad-Akad Illegal

a. Akad yang mengandung riba

b. Akad yang mengandung perjudian

c. Jual beli yang mengandung gharar (dengan tipu daya)

d. Mulamasah, yaitu jual beli zaman jahiliyah yaitu dengan cara meraba-raba barang dagangan

${ }^{13}$ Lukman Hakim, Prinsip-Prinsip Ekonomi Islam, (Surakarta : Airlangga, 2012), hal 166 
e. Munabazah, yaitu jual beli dengan cara melempar barang dagangan batu kerikil, dimana kerikil jatuh maka barang yang dijatuhi kerikil harus dibeli

f. Jual beli najsy atau tsuna'niyah, jika tujuannya adalah mengambil dirham dengan dirham yang lebih banyak darinya sampai masa tertentu.

3. Mencegat Barang Sebelum Sampai di Pasar

Produsen dilarang mencegat pedagang dipinggir kota, demi mendapat keuntungan dari ketidaktahuan penjual dari satu kota terhadap harga yang berlaku di kota lain. Sebagaimana hadits Rasulullah SAW: "Janganlah kamu cegat (jemput kafilah sebelum sampai di kota). Barang siapa dicegat lalu dibeli daripadanya sesuatu, maka apabila yang empunya barang itu datang ke pasar, ia berhak khiyar (hak menentukan jadi atau batalnya penjualan)" (H.R. Muslim dari Abu Hurairah)

4. Dilarang Menimbun Barang

Segala bentuk penimbunan dilarang dalam Islam, karena menyebabkan terjadinya kelangkaan barang di pasar, sehingga harga-harga mengalami kenaikan. Rasulullah SAW bersabda: "Ia yang menimbun adalah orang yang berdosa" (H. R. Muslim dalam sahihnya). Penimbunan adalah halangan terbesar dalam pengaturan persaingan dalam pasar Islam. Hal tersebut dikarenakan pengaruhnya terhadap jumlah barang yang tersedia dari barang yang ditimbum, dimana beberapa pedagang memilih untuk menahan barang dagangannya dan tidak menjualnya karena menunggu naiknya harga.

Demikian juga barang-barang yang tidak berkaitan secara langsung dengan barang-barang yang ditimbun, mengakibatkan harga barang lain juga akan naik. Sehingga tingkat konsumsi masyarakat akan menurun dan pada gilirannya akan mengurangi tingkat produksi.

5. Monopoli Perdagangan

Monopoli perdagangan adalah penjual membuat komitmen agar yang menjual bahan makanan atau lainnya hanya kepada orang-orang tertentu yang sudah dikenal. Barang-barang itu tidak dijual selain kepada mereka, kemudian mereka menjualnya, seandainya ada orang lain yang menjualnya, maka dilarang. Ini merupakan kezhaliman terhadap tugas dan wewenang penjual yang dilarang dalam Islam.

Mekanisme pasar sebagaimana dikonsepkan para pemikir Islam Klasik : ${ }^{14}$

a. Permintaan

Permintaan merupakan salah satu elemen penggerak pasar. Faktor-faktor yang mempengaruhi permintaan sbb:

${ }^{14}$ Eko Listianto, Kenaikan Harga Minyak Dunia : Penyebab dan Dampaknya terhadap Subsidi Energi di Indonesia, Jurnal Bisnis dan Ekonomi Politik Quarterly Review of The Indonesian Economy Subsidi dalam Perekonomian Indonesia, Volume 9, Nomor 3, Juli 2008. 
1) Harga barang yang bersangkutan;

Pada umumnya hubungan antara tingkat harga dan jumlah permintaan adalah negatif. Semakin tinggi tingkat harga maka semakin rendah jumlah permintaan, demikian sebaliknya.

2) Efek subtitusi;

Jika harga suatu barang naik, maka hal ini akan mendorong konsumen untuk mencari barang lain yang bisa menggantikan fungsi barang yang harganya naik tersebut

3) Efek pendapatan;

Jika harga suatu barang naik maka berarti pula secara riil pendapatan konsumen turun sebab dengan pendapatan yang sama ia hanya dapat membeli barang sedikit

4) Pendapatan konsumen;

Semakin tinggi pendapatan konsumen, maka semakin tinggi daya belinya sehingga permintaannya terhadap barang akan meningkat pula.

5) Harga barang lain yang terkait;1

Yang dimaksud barang lain yang terkait adalah harga barang subtitusi (pengganti) dan komplementer (pelengkap)

6) Selera konsumen;

Jika selera konsumen terhadap barang tersebut tinggi maka permintaannya pun akan tinggi meskipun harganya tinggi dan begitupun sebaliknya

7) Ekspektasi (penghargaan);

Ekspektasi bisa positif dan bisa negatif. Dalam kasus ekspektasi positif konsumen akan lebih terdorong untuk membeli suatu barang, dan untuk negatif berlaku sebaliknya

8) Maslahah;

Pengaruh mashlahah terhadap permintaan tidak bisa dijelaskan secara sederhana sebab ini tergantung pada tingkat keimanan.

b. Penawaran

Dalam khasanah pemikiran ekonomi Islam klasik, pasokan (penawaran) telah dikenal sebagai kekuatan penting di dalam pasar. Ibnu Taimiyah mengistilahkan penawaran ini sebagai ketersedian barang di pasar:

1) Mashlahah;

Pengaruh mashlahah terhadap penawaran pada dasarnya tergantung pada tingkat keimanan produsen. Jika jumlah mashlahah yang terkandung dalam barang yang diproduksi semakin meningkat, maka produsen muslim akan memperbanyak jumlah produksinya.

2) Keuntungan; 
Keuntungan merupakan bagian dari mashlahah Karena ia dapat mangakumulasi modal pada akhirnya dapat digunakan sebagai aktivitas lainnya. Faktor-faktor yang mempengaruhi keuntungan adalah:

3) Harga barang;

Jika harga suatu barang naik maka keuntungan akan naik pula

4) Biaya produksi;

Biaya produksi jelas menentukan tingkat keuntungan sebab keuntungan merupakan selisih dari penerimaan dengan biaya produksi. Jika biaya turun maka keuntungan produsen akan meningkat, dan hal ini mendotrongnya untuk meningkatkan penawaran.

\section{PENETAPAN HARGA DALAM ISLAM}

Konsep Islam memahami bahwa pasar dapat berperan efektif dalam kehidupan ekonomi bila prinsip persaingan bebas dapat berlaku secara efektif. Pasar tidak mengharapkan adanya intervensi dari pihak mana pun, tak terkecuali negara dengan otoritas penentuan harga atau private sector dengan kegiatan monopolistik atau lainnya.

Karena pada dasarnya pasar tidak membutuhkan kekuasaan yang besar untuk menentukan apa yang harus dikonsumsi dan diproduksi. Sebaliknya, biarkan tiap individu dibebaskan untuk memilih sendiri apa yang dibutuhkan dan bagaimana memenuhinya. Inilah pola normal dari pasar atau "keteraturan alami" dalam istilah Al-Ghazali berkait dengan ilustrasi dari evolusi pasar. Selanjutnya Adam Smith, menyatakan serahkan saja pada invisible hand, dan "dunia akan teratur dengan sendirinya". Dasar dari keutusan para pelaku ekonomi adalah voluntary, sehingga otoritas dan komando tidak lagi terlalu diperlukan. ${ }^{15}$

Harga sebuah komoditas barang dan jasa ditentukan oleh penawaran dan permintaan, perubahan yang terjadi pada harga berlaku juga ditentukan oleh terjadinya perubahan permintaan dan perubahan penawaran. Hal ini sesuai dengan hadits yang diriwayatkan dari Anas bahwasanya suatu hari terjadi kenaikan harga yang luar biasa di masa Rasulullah SAW, maka sahabat meminta Nabi untuk menentukan harga pada saat itu, lalu Nabi besabda:

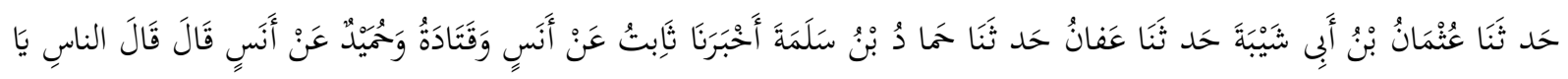

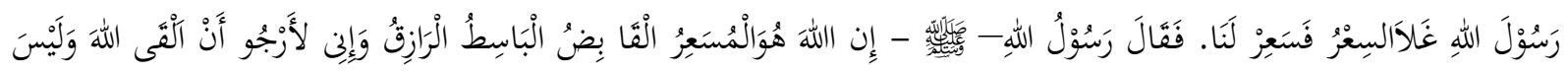

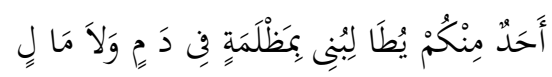

Artinya "Ya Rasulullah telah terjadi kenaikan harga-harga barang maka tetapkan harga untuk barang-barang tersebut. Rasulullah menjawab : sesungguhnya Allah yang 
maha penetap harga, yang menyempitkan dan melapangkan serta pemberi rezeki, saya berharap akan bertemu dengan Allah dan tidak seorang pun yang menuntut saya karena kezaliman yang saya lakukan dalam masalah darah dan harta" (H. R. Bukhari, Muslim, Abu Daud dan Ahmad).

Dari hadits itu dapat disimpulkan bahwa pada waktu terjadi kenaikan harga Rasulullah SAW, meyakini adanya penyebab tertentu yang sifatnya darurat. Oleh sebab itu, sesuatu yang bersifat darurat akan hilang seiring dengan hilangnya penyebab dari keadaan itu. Dilain pihak Rasul juga meyakini bahwa harga akan kembali normal dalam waktu yang tidak terlalu lama (sifat darurat). Penetapan harga menurut Rasul merupakan suatu tindakan yang menzalimi kepentingan para pedagang, karena para pedagang di pasar akan merasa terpaksa untuk menjual barangnya sesuai dengan harga patokan, yang tentunya yang tentunya tidak sesuai dengan keridhaannya.

Dengan demikian, pemerintah tidak memiliki wewenang untuk melakukan intervensi terhadap harga pasar dalam kondisi normal. Ibnu Taimiyah mengatakan jika masyarakat melakukan transaksi jual beli dalam kondisi normal tanpa ada bentuk distorsi atau penganiayaan apa pun dan terjadi perubahan harga karena sedikitnya penawaran atau banyaknya permintaan.

Harus diyakini bahwa nilai konsep Islam tidak memberikan ruang intervensi dari pihak mana pun untuk menentukan harga, kecuali dan hanya kecuali adanya kondisi darurat yang kemudian menuntut pihak-pihak tertentu untuk ambil bagian menentukan harga. ${ }^{16}$

Dalam Islam, tingkat harga diserahkan pada kekuatan permintaan dan penawaran. Dalam keadaan pasar berjalan secara alami pemerintah tidak dibenarkan ikut campur tangan dalam mekanisme pasar. Berdasarkan hadits yang telah dibahas sebelumnya bahwa penentu harga adalah Allah, maksudnya diserahkan kepada penawaran dan permintaan. Penolakan Rasulullah terhadap penetapan harga (tas'ir) berdasarkan hadits ini adalah karena tidak ditemukannya kondisi yang mengharuskan untuk melakukannya karena kenaikan harga yang terjadi masih dalam keadaan normal bukan akibat distorsi pasar. Ketika harga terbentuk karena supply dan demand yang apabila dilakukan intervensi akan menimbulkan kezaliman bagi banyak pihak.

Namun, apabila harga barang di pasar tidak lagi ditentukan oleh kekuatan permintaan dan penawaran, seperti melonjaknya harga suatu barang disebabkan oleh hilangnya barang di pasaran karena ikhtikar (penimbunan barang komoditi tertentu yang sangat dibutuhkan oleh masyarakat), atau kenaikan suatu barang disebabkan oleh ketiadaan barang komoditi karena bencana alam. Dalam keadaan seperti ini, menurutIbnu Taimiyah, pemerintah dapat melakukan intervensi pasar dalam rangka menentukan harga. ${ }^{17}$

${ }^{16}$ Ibid., 161

${ }^{17}$ Abdul Azhim Islahi, Economic Consepts of ibnu Taimiyah, (London : The Islamic Foundation, 1998), hal 98 
Pendapat Ibnu Taimiyah ini sama dengan pendapat Ibnu Qayyim yang menyatakan penentuan harga harus diserahkan pada kekuatan pasar, yaitu kekuatan permintaan dan penawaran, jika terjadi ketidaksempurnaan pasar (distorsi), seperti monopoli, Ibnu Qayyim merekomendasikan intervensi pemerintah untuk memperbaiki harga pasar. ${ }^{18}$

Dalam konsep Islam, cara pengendalian harga ditentukan oleh penyebabnya. Bila penyebabnya adalah perubahan pada permintaan dan penawaran, maka mekanisme pengendalian dilakukan melalui intervensi pasar. Bila penyebabnya adalah distorsi terhadap permintaan dan penawaran maka pengendalian dilakukan dengan menghilangkan distorsi tersebut.

Intervensi pasar menjadi sangat penting dalam menjamin ketersediaan barang kebutuhan masyarakat. Dalam keadaan kekurangan barang kebutuhan pokok, pemerintah dapat membuat aturan agar pedagang tidak menjual barang ke luar wilayah, ataupun dengan membuat kebijakan agar produsen meningkatkan produksinya guna meningkatkan jumlah kebutuhan pokok di pasar. ${ }^{19}$

Inilah bentuk peran negara dalam mekanisme pasar sebagai regulator, mengawasi dan mengatur mekanisme pasar agar berjalan seimbang, sehingga tercipta harga yang adil (equilibrium price). Dalam perspektif ekonomi Islam, equilibrium price adalah harga yang tidak menimbulkan dampak negatif ataupun kerugian bagi para penjual maupun pembeli. ${ }^{20}$ Menurut Said Saad Marathon, harga tidak dapat dikatakan adil apabila harga tersebut terlalu rendah sehingga penjual tidak dapat menutup biaya-biaya yang telah dikeluarkannya dan tidak boleh terlalu tinggi karena akan memberatkan konsumen. Harga yang adil adalah harga yang dapat menutupi semua biaya operasional produsen dengan tingkat laba tertentu serta tidak merugikan konsumen. Dalam hal ini, Ibnu Taimiyah berpendapat apabila harga yang terbentuk tidak merefleksikan kerelaan masing-masing pihak dan tidak terdapat persentase keuntungan tertentu maka hal tersebut akan menyebabkan distorsi harga dan dapat merugikan manusia. ${ }^{21}$

Dalam rangka melindungi hak penjual dan pembeli, Islam membolehkan bahkan mewajibkan melakukan intervensi harga. Ada beberapa faktor yang membolehkan intervensi harga, yaitu sebagai berikut:

1. Intervensi harga menyangkut kepentingan masyarakat yaitu melindungi penjual dalam hal profit magin (keuntungan), dan pembeli dalam hal purchasing power (Kemampuan pembeli). Jika harga tidak ditetapkan ketika penjual menjual dengan harga tinggi yang dapat merugikan pembeli

2. Intervensi harga mencegah ikhtikar atau ghaban fâhisy

\footnotetext{
${ }^{18}$ Rozalinda, Ekonomi Islam Teori... hal 164-165

${ }^{19}$ Ibid.

${ }^{20}$ Said Sa'ad Marathon, Al-Madkhal li al-Fikr al-Ikhtishad fi al-Islam, (Riyadh : Maktabah a-Riyad, 2001), hal 
3. Intervensi harga melindungi kepentingan masyarakat yang lebih luas karena pembeli biasanya mewakili masyarakat yang lebih luas. Sedangkan penjual mewakili kelompok yang lebih kecil..22

Dalam menetapkan harga para ulama Fiqih berbeda pendapat, sebagian ulama membenarkan negara untuk menetapkan harga, sebagian lagi menolak. Ulama Zahiriyah, sebagian ulama Malikiyah, sebagian ulama Syafi'iyah, sebagian ulama Hanabilah dan Imam Asy-Syaukani menyatakan berdasarkan hadits ini dalam kondisi apapun penetapan harga oleh pemerintah tidak dapat dibenarkan, jika dilakukan hukumnya haram. Pematokan harga merupakan suatu kezaliman. Menurut mereka, baik harga itu melonjak tinggi yang disebabkan oleh tingginya permintaan, maupun ulah spekulan maupun faktor alam, segala bentuk campur tangan pemerintah dalam penetapan harga tidak dibolehkan. Apabila pemerintah ikut campur tangan dalam penetapan harga komoditi, berarti unsure penting dari jual beli yaitu antarhadin para pihak hilang. Ini berarti pemerintah telah membuat kezaliman kepada para pihak yang melakukan jual beli. Alasannya bahwa manusia berkuasa atas harta mereka sedangkan pematokan harga adalah pemaksaan terhadap mereka.

Ibnu Qudamah al-Maqdisi, salah seorang pemikir terkenal dari Mahzab Hambali berpendapat, Imam (pemerintah) tidak memiliki wewenang untuk menetapkan harga bagi penduduk, penduduk boleh menjual barang mereka dengan harga berapapun yang mereka sukai. Ibnu Qudamah menjadikan hadits yang dibahas sebelumnya sebagai landasan tidak diperkenankannya penetapan harga. Pertama, Rasulullah tidak pernah menetapkan harga meskipun penduduk menginginkan. Bila itu dibolehkan pasti Rasulullah akan melaksanakannya. Kedua, menetapkan harga adalah suatu ketidakadilan (zulm) yang dilarang.

Ibnu Qudamah menganalisis bahwa penetapan harga oleh pemerintah tidaklah menguntungkan. Ia berpendapat bahwa penetapan harga akan mendorong harga menjadi lebih mahal. Jika pedagang dari luar mendengar adanya kebijakan penetapan harga, mereka tidak akan mau menjual barang dagangannya ke wilayah dimana ia dipaksa menjual barang dagangannya di luar harga yang dia inginkan. Para pedagang lokal yang memiliki barang dagangan akan menyembunyikan barang dagangannya. Para konsumen yang membutuhkan barang-barang tidak bisa memenuhi permintaan mereka karena harganya tinggi. Akhirnya kedua belah pihak menderita.

Mahzab Hanafi dan Syafi'I menyatakan bahwa negara tidak mempunyai hak untuk menetakan harga. Jumhur ulama berpendapat penetapan harga oleh pemerintah hukumnya haram. Namun, Ibnu Taimiyah menolak pendapat Jumhur Ulama yang mengharamkan secara mutlak penetapan harga tersebut. Sejumlah ahli Fiqih Islam mendukung kebijakan

${ }^{22}$ Rozalinda, Ekonomi Islam Teori .... hal 169 
pengaturan harga, walaupun baru dilaksanakan dalam situasi genting dan menekankan perlunya kebijakan harga yang adil.

Ibnu Taimiyah menguji pendapat-pendapat dari keempat Mahzab itu, menurutnya "kontroversi antar para ulama berkisar dua poin", Pertama, jika terjadi harga yang tinggi di pasar dan seseorang berusaha menetapkan harga yang lebih tinggi daripada harga sebenarnya, perbuatan mereka itu menurut Mahzab Maliki harus dihentikan. Menurtu Syafi'I dan dan penganut Ahmad Hanbal, seperti Abu Hafzal-Akbari, Qadi Abu Ya'la dan lainnya, mereka tetap menentang berbagai campur tangan terhadap keadaan ini.

Kedua, dari perbedaan pendapat antar para ulama adalah penetapan harga maksimum bagi para pedagang dalam kondisi normal. Inilah pendapat yang bertentangan dengan mayoritas para ulama, bahkan oleh Maliki sendiri. Tetapi beberapa ahli, seperti Sa'id bin Musayyib, Rabiah bin Abdul Rahman dan Yahya bin Sa'id menyetujuinya. Para pengikut Abu Hanifah berkata bahwa otoritas harus menetapkan harga, hanya bila masyarakat menderita akibat peningkatan harga itu, dimana hak penduduk harus dilindungi dari kerugian yang diakibatkan oleh penetapan harga tersebut.

Ibun Taimiyah menjelaskan bahwa jika harga itu bisa ditetapkan untuk memenuhi kebutuhan satu orang saja, pastilah akan lebih logis kalau hal itu ditetapkan untuk memenuhi kebutuhan produk atas produk makanan, pakaian, perumahan, karena kebutuhan umum itu jauh lebih penting daripada kebutuhan seorang individu.

Istilah harga yang adil dalam Islam, dijumpai dalam beberapa terminology, antara lain si'r al-mithl, thaman al mithl dan qimah al-adl. Istilah qimah al-adl (harga yang adil) pernah digunakan Rasulullah SAW dalam mengomentari konpemsasi bagi pembebasan budak, dimana budak ini akan menjadi manusia merdeka dan majikannya tetap memperoleh konpemsasi dengan harga yang adil atau qimah al-adl (Shahih Muslim). Penggunaan istilah ini juga ditemukan dalam laporan tentang khilafah Umar bin Khattab dan Ali bin Abi Thalib. Umar bin Khattab menggunakan istilah harga yang adil ini ketika menetapkan nilai baru atas diyah (denda/uang tebusan darah), setelah nilai dirham turun sehingga hargaharga naik (Ibnu Hanbal) ${ }^{23}$

Meskipun istilah-istilah di atas telah digunakan sejak masa Rasulullah dan Khulafaurrasyidin, tetapi sarjana Muslim yang pertama yang memberikan perhatian khusus adalah Ibnu Taimiyah. Ibnu Taimiyah sering menggunakan dua terminology dalam pembahasan harga ini, yaitu 'iwad al-mithl (equivalen compensation/kompensasi yang setara) dan thaman al-mithl (equivalen price/harga yang setara). Dalam Al Hisbah, karangannya ia mengatakan "kompensasi yang setara dan itulah esensi keadilan (nafs al-adl). Dalam Majmu Fatawa karangannya Ibnu Taimiyah menjelaskan equivalen price sebagai harga baku (si'ir) di mana penduduk menjual barang-barang mereka dan secara umum diterima sebagai sesuatu

${ }^{23}$ Pusat Pengkajian dan Pengembangan Ekonomi Islam..., hal 331 
yang setara dengan itu dan untuk barang yang sama pada waktu dan tempat yang khusus. Sementara dalam Al-Hisbah, ia menjelaskan bahwa equivalen price ini sesuai dengan keinginan atau lebih persisnya harga yang ditetapkan oleh kekuatan pasar yang berjalan secara bebas-kompetitif dan tidak terdistorsi-antara penawaran dan permintaan.

Dalam Islam istilah penetapan harga oleh pemerintah dikenal dengan At-tas'ir aljabari. Kata At-tas'ir yang berarti penetapan harga. Sedangkan al-jabari berarti secara paksa. Beberapa rumusan yang dikemukakan oleh ulama Fiqih. Ulama Hanbali mendefenisikan Attas'ir al-jabari "upaya pemerintah dalam menetapkan harga suatu komoditi, serta memberlakukannya dalam transaksi jual beli warganya". ${ }^{24}$ Imam Asy-Syaukani mendefenisikan "instruksi pihak penguasa kepada para pedagang agar mereka tidak menjual barang dagangannya kecuali sesuai dengan ketentuan harga yang telah ditetapkan pemerintah dengan tujuan kemaslahatan bersama" Kemudian pakar Fiqih Maliki yaitu Ibn 'Urfah al-Maliki, mendefenisikan "Penetapan harga oleh pihak penguasa terhadap komoditi yang bersifat konsumtif"

\section{TELAAH INTERVENSI PEMERINTAH DALAM SUBSIDI ATAU MENETAPKAN HARGA BBM}

Dari penjelasan di atas dijelaskan bahwa sistem pasar dalam Islam adalah sistem pasar bebas. Bebas bukan berarti bebas seutuhnya tapi berada dalam frame aturan syariah. Dalam Islam, tingkat harga diserahkan sepenuhnya pada kekuatan permintaan dan penawaran. Dalam keadaan pasar berjalan secara alami pemerintah tidak dibenarkan ikut campur tangan dalam mekanisme pasar. Berdasarkan hadits yang telah dibahas sebelumnya bahwa penentu harga adalah Allah, maksudnya diserahkan kepada penawaran dan permintaan.

Melihat masalah kenaikan harga BBM di Indonesia, selama ini pemerintah memberikan subsidi untuk meringankan biaya rakyat. Walaupun harga minyak dunia mengalami kenaikan tidak akan ada pengaruhnya terhadap harga minyak di Indonesia selagi pemerintah Indonesia tidak menaikkan harga BBM. Itu merupakan intervensi pemerintah Indonesia dalam membantu meringankan biaya masyarakat.

Secara teoritis kebijakan subsidi BBM merupakan kebijakan pemerintah dalam rangka membantu konsumen (masyarakat) agar mendapatkan harga BBM pada tingkat harga yang lebih murah dengan sebagian beban harga ditanggung pemerintah. Dengan harga yang lebih terjangkau maka akan semakin banyak masyarakat yang bisa mengakses BBM. Pada gilirannya penggunaan BBM akan meningkatkan pertumbuhan ekonomi melalui makin aktifnya kegiatan produksi dan distribusi barang dan jasa termasuk kegiatan transportasi.

Tujuan pemerintah adalah untuk kemaslahan rakyat, supaya tidak dibebani dengan biaya yang terlalu tinggi. Kalau harga minyak diserahkan kepada mekanisme pasar dan

${ }^{24}$ Nasrun Haroen, Fiqih Muamalah, (Jakarta : Gaya Media Pratama, 2000), hal 139 
pemerintah tidak melakukan intervensi lagi, maka rakyat Indonesia akan menanggung biaya yang tinggi apabila harga minyak dunia melonjak naik.

Meskipun menurut mekanisme pasar islami, pemerintah tidak boleh intervensi harga, karena harga ditetapkan oleh mekanisme pasar, -- kecuali dalam keadaan tertentu, seperti adanya ihtikar (penimbunan barang), kecurangan, distorsi harga dan lainnya--, akan tetapi untuk kemaslahatan masyarakat yang belum mampu merata secara ekonomi mengikuti harga pasar minyak dunia tanpa subsidi, dan dalam hal ini pemerintah harus intervensi harga, maka hal itu dibolehkan. Hal ini sesuai dengan kaidah fiqh yang berbunyi:

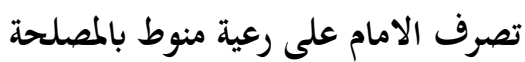

Artinya: "Tindakan seorang penguasa terhadap rakyatnya harus senantiasa mengacu kepada maslahah"25

Dari kaidah ini dapat disimpulkan bahwa tindakan pemerintah dalam menetapkan harga BBM merupakan suatu kemaslahatan dengan tetap mempertimbangkan keadilan dan kemakmuran masyarakat.

\section{PENUTUP}

Berdasarkan uraian di atas, dapat disimpulkan bahwa dalam konsep mekanisme pasar secara islami, harga-harga komoditi ditetapkan oleh mekanisme pasar, artinya harga berlaku tergantung kepada permintaan dan penawaran. Akan tetapi dalam keadaan tertentu seperti penetapan harga BBM yang mengalami turun-naik tergantung harga minya dunia, maka pemerintah boleh intervensi harga demi kemaslahatan dan melindungi kepentingan rakyat yang belum merata kemampuannya secara ekonomi. Karena tindakan intervensi oleh pemerintah tersebut berlandaskan kepada kemaslahatan dan kesejahteraan masyarakat.

${ }^{25}$ Imam Alam Syahibuddin al-Qarafi, al-Furuq, (Beirut: Alim al-Maktab, t.th), h. 31 


\section{DAFTAR PUSTAKA}

Hakim, Lukman, Prinsip-Prinsip Ekonomi Islam, Surakarta : Airlangga, 2012

Haroen, Nasrun, Fiqih Muamalah, Jakarta : Gaya Media Pratama, 2000

Islahi, Abdul Azhim, Economic Consepts of ibnu Taimiyah,London : The Islamic Foundation, 1998

Eko Listiyanto, Kenaikan Harga Minyak Dunia : Penyebab dan Dampaknya terhadap Subsidi Energi di Indonesia, Jurnal Bisnis dan Ekonomi Politik Quarterly Review of The Indonesian Economy Subsidi dalam Perekonomian Indonesia, Volume 9, Nomor 3, Juli 2008

Marathon, Said Sa'ad, Al-Madkhal li al-Fikr al-Ikhtishad fi al-Islam, (Riyadh : Maktabah a-Riyad, 2001

Nasution, Mustafa Edwin, dkk, Pengenalan Ekflusif Ekonomi Islam, Jakarta : Kencana, 2007

Pusat Pengkajian dan Pengembangan Ekonomi Islam (P3EI), Ekonomi Islam,Jakarta : Rajawali Pers, 2009

al-Qarafi, Imam Alam Syahibuddin, al-Furuq, Beirut: Alim al-Maktab, t.th

Shihab, M. Quraish, Tafsir Al Misbah, Jakarta:Lentera hati, 2002

Rozalinda, Ekonomi Islam Teori dan Aplikasinya pada Aktivitas Ekonomi, Jakarta : Rajawali Pers, 2014

Wahyudi, Arif, Telaah Kritis Pemikiran Ekonomi Islam terhadap Mekanisme Pasar dalam Konteks Ekonomi Islam Kekinian, Jurnal Eksyar, Volume 01, Nomor 01, Maret 2014 STAI Muhammadiyah Tulung Agung

http://economy.okezone.com/read/2014/08/28/19/1030923/sejarah-harga-bbm-subsidi-diindonesia, 27 Januari 2015, 15.00

http://tinoberita.blogspot.com/2014/12/harga-bbm-akan-turun-di-akhir-tahun.html. Januari 2015, 15.10 
FITRAH Vol.01 No. 1 Januari-Juni 2015

Pengalihan Dana Zakat Menjadi Pinjaman Modal Usaha Oleh BAZDA Kota Padang Dalam Perspektif Al-Qur'an Dan Hadits 